\title{
A P.E.S.T. ANALYSE OF THE MARKETING ENVIRONMENT OF THE ROMANIAN SME SECTOR DURING THE LAST FINANCIAL CRISIS YEARS
}

\author{
Mariana Lucreția Constantinescu ${ }^{l}$, \\ Andreea Cojoaca (Panagoreț) ${ }^{2}$
}

\begin{abstract}
The health of an economy depends, no doubt, by the dynamic of SME sector and their level success on the domestic and international markets.

Our work aims a PESTLE analysis of the Romanian SME sector after 2008 year when they were felt the effects of the global financial crisis and to emphasize the powerful adaptive management process continues to change the demand and to identify, also, the effective tactics to the companies level to reduce the negative impacts and threats because of the macroeconomic context of today, less favorable to SME of Romania.

The reflection will bring the possible macroeconomic and sectorial consequences in terms for the economy of Romania in the coming years and the measures that must be take in place to mitigate these consequences of the Romanian SME sector which represents $96 \%$ of the Romanian economy.
\end{abstract}

Key words: marketing environment turbulence, financial crisis, macroeconomic consequences, Romanian SME sector dynamic, sector attractiveness

JEL classification: M16, M21, M31, O52

\section{Introduction}

The Romanian SME activity was influenced by several factors:

- the transition to market economies of the former socialist countries of the Central and Eastern Europe and increasing the attractiveness of these countries due to economic reforms and integration into Euro-Atlantic structures, as in the case of Romania;

- the market globalization process has intensified the environmental turbulence of this sector ;

- the technological absorbtion capacity from the Romanian economy - the technology is seen as a superposition of technologies that together may create a competitive advantage into the value chain of the company;

The country competitiveness, its criteria and the modalities to implement a dominate position to the international economy and the global economy becomes a huge battlefield where only survive "the winners". In the economic systems based on the efficient markets existence where the company may sell unrestricted their products and services, the firms can be considered as an instrument to satisfy the consumer needs.

J.C. Trichet considered that "an important consequence of the European Union opening is that the European companies must adopt an internationalization strategy by which the enterprises provide an advantage competitive sources"( Trichet J.C., 2009)

The most developing countries follow in succession a set of sequences in the process of technological diffusion that begins with the standardized technologies importation, imitation,

\footnotetext{
${ }^{1}$ Valahia University of Targoviste, Romania. e-mail: maractinescu@gmail.com

${ }^{2}$ Valahia University of Targoviste, Romania.e-mail: cojoaca.andreea@yahoo.com
} 
adaptation, transformation and finally the export of intermediate technology. However, when agreements with foreign partners, a fear may arise for business guests that relying exclusively on the key skills developed partner. This strong position may decide to take a financial advantage and capture the bulk of the value created by the alliance. These divergent interests may hinder the effects that could derive from this interaction (Lynch R, 2001)

During the years after the NATO joining, Romania has attracted foreign direct investments (FDI) in value of 28.1 billion euros with an average of 5.6 billion euros per year. In 2008, after the EU accession, our country has registred the highest growth rate (see graph. 1).

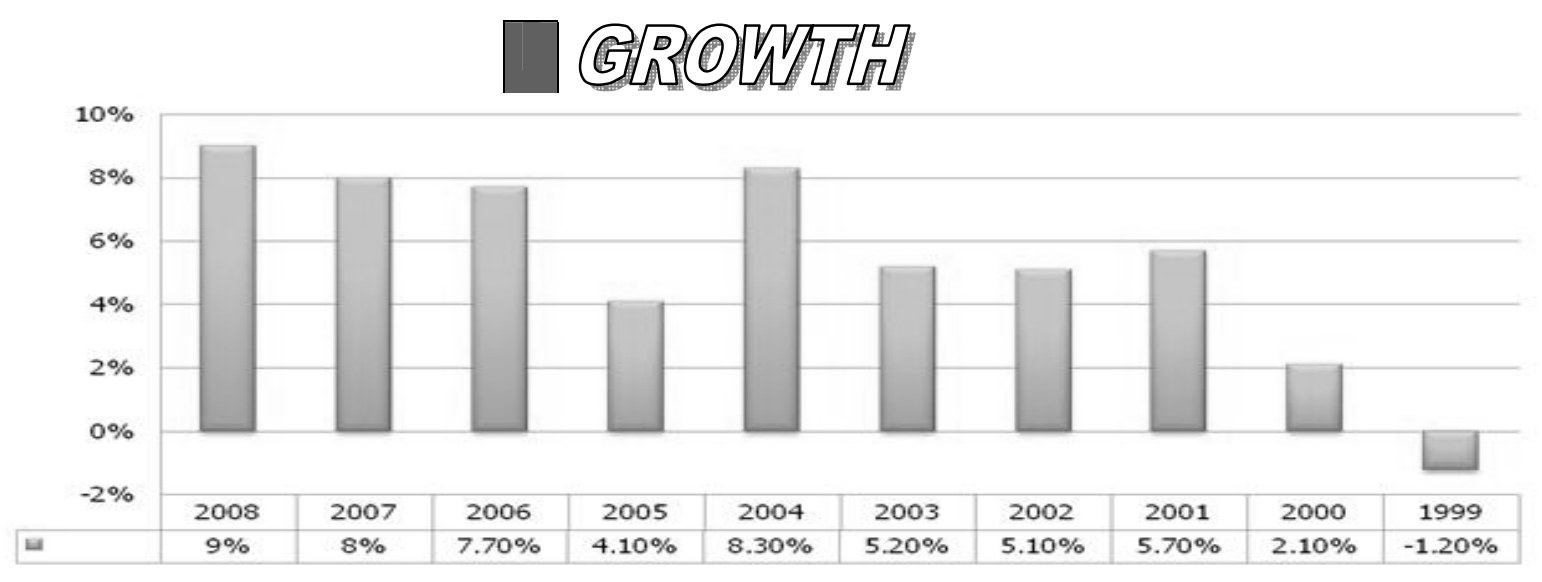

Fig.no. 1 -Romanian economic growth rate between $1999-2008$

For SME sector of Romania, the EU accession has opened a perspective focus to the emergence might be called "the economy of adhesion", which requires them to transformation processes having as objective the initiation and support of trends to growth the Romania's competitiveness. No doubt, the accession of Romania to the EU has change the business environment of the our country with large strategic implications and overwhelming on all areas of the Romanian economy, including SME, also.

\section{financial crisis}

P.E.S.T.L.E. analyse of the Romanian SME sector under the impact of the latest

Since 1989, D.C.E. no.244/1997 for improving and simplifying the business environment has encouraged EU Member States to implement measures to improve and simplify the business environment, with respect to the creation of new SME and help them in the first year of their creation to release a potential for innovation, encourage the growth of these businesses and to create, too, the new jobs of work.

The business climatic changes during the 15 last years of Romania provided to an extensive development of the SME sector which in the present days it represents the engine of the development of the Romanian economy ( see tabel.1) . 
Table no. 1.

Comparative evolution of the SME number of Romania during 2006-2008 years

\begin{tabular}{|c|c|c|c|c|}
\hline Activity branch & 2005 & 2006 & 2007 & 2008 \\
\hline Mines industry & 584 & 642 & 707 & 879 \\
\hline Manufacturing industry & 54080 & 56765 & 57835 & 58953 \\
\hline $\begin{array}{l}\text { Electrical and termic energy, natural gaze and water } \\
\text { branch }\end{array}$ & 364 & 379 & 412 & 529 \\
\hline Construction sector & 25199 & 30204 & 35954 & 46740 \\
\hline $\begin{array}{l}\text { Commerce sector, automotive, motocyles, } \\
\text { personal\&household goods repair sector }\end{array}$ & 191077 & 200246 & 205787 & 211359 \\
\hline Hospitality sector & 19800 & 20324 & 20554 & 22063 \\
\hline Transport, communication\& storage services & 25015 & 28810 & 31969 & 36379 \\
\hline $\begin{array}{l}\text { Transaction estate, rent and business } \\
\text { consulting service sector }\end{array}$ & 61089 & 74200 & 83828 & 95662 \\
\hline Education & 1075 & 1365 & 1669 & 2150 \\
\hline Health and social assistence sector & 6832 & 7839 & 8537 & 9285 \\
\hline Other social, community and personnel services & 10016 & 11481 & 12684 & 14016 \\
\hline
\end{tabular}

The foreign investors' orientation to the Romanian economic branches (according to CAENRev.2), located FDI, firstly, to the manufacturing industry (31.3\% of total). The most attractive for FDI being : metallurgy industry (6.9\% of total), food industry, beverages and tobacco $(4.6 \%)$, petroleum processing, chemicals, rubber and plastics $(4.3 \%)$, transportation sector (4\%), cement, glass, ceramics industry (3.6\%). We still notice a low share compared to their potential for areas such as textile, clothing and leather industry which represents only $1.6 \%$ of total FDI. (see graph. 2).

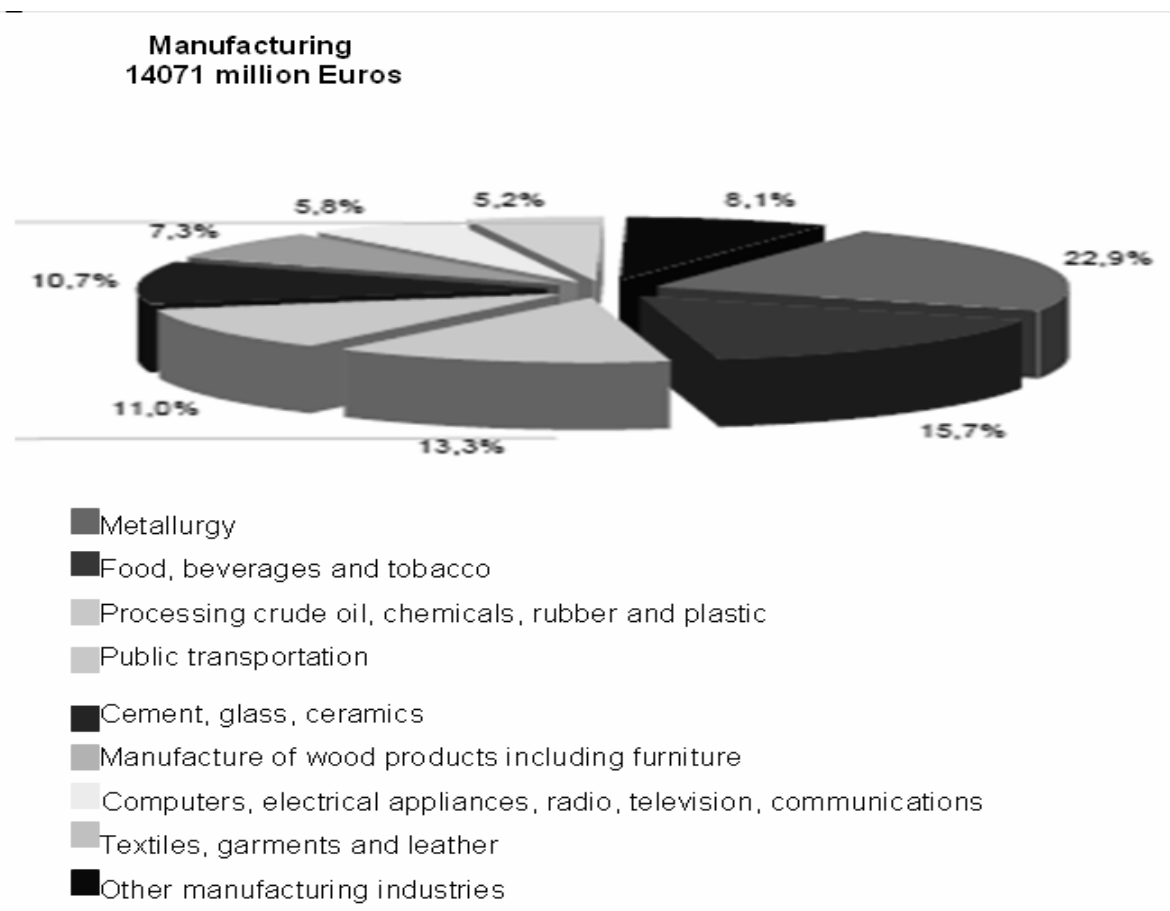

Fig.no. 2. - FDI Distribution by the Romanian manufacturing branch in 2008 year

Other activities which have attracted significant FDI were: financial intermediation services including banking, non-bank financial institutions and insurance (20.5\% of total FDI), construction and real estate $(12.6 \%)$, trade $(12.4 \%)$, and the ICT sector $(6.7 \%)$. 
The turnover of SME in 2010 with foreign participation account for $37 \%$ of sales of small and medium sized private companies of Romania and the areas with the largest share of FDI are in the area of Bucharest and Northern West and West regions of our country

During the $4^{\text {th }}$ Quarter $/ 2008$, the global economic crisis began to unfold and Romania and the economic downturn has become a reality. Available data show a significant reduction of the industrial activity, including volume growth in service sector activities and buildings and during 2009, continued the decline of certain industries (e.g. textiles, metal, furniture, etc.) The magnitude of economic growth was sustained in the first half of the year for significant contributions in other branches of production industrial. In 2010, the Romanian economy openness expanded again to more than 75 percent, after a 10-year low of $67.6 \%$ in 2009. Integration with the European Union in terms of trade, quaranteed by the share of trade with the other EU Member States in Romania's total foreign trade, remained high, i.e. above $70 \%$ in 2010 . Regarding to agriculture sector, after the first year of developments that have been modest, Romania obtained significant results for the summer grain crops (wheat, barley, etc.).

During 2010, although the volume of FDI was smaller in comparison with 2009 and the consumption was the engine of economic growth but Romania has escaped more. Romanian increased in value significant adjustments in their structure that does mean the need of the Romanian economy to new technologies, machinery and industrial equipment performance, raw materials and energy. In addition, it appears that more than half of imports are products of higher technological complexity that shows the relatively low level of the Romanian economic development that it will provide negative consequences into the Romania's trade balance (see graphic 3).

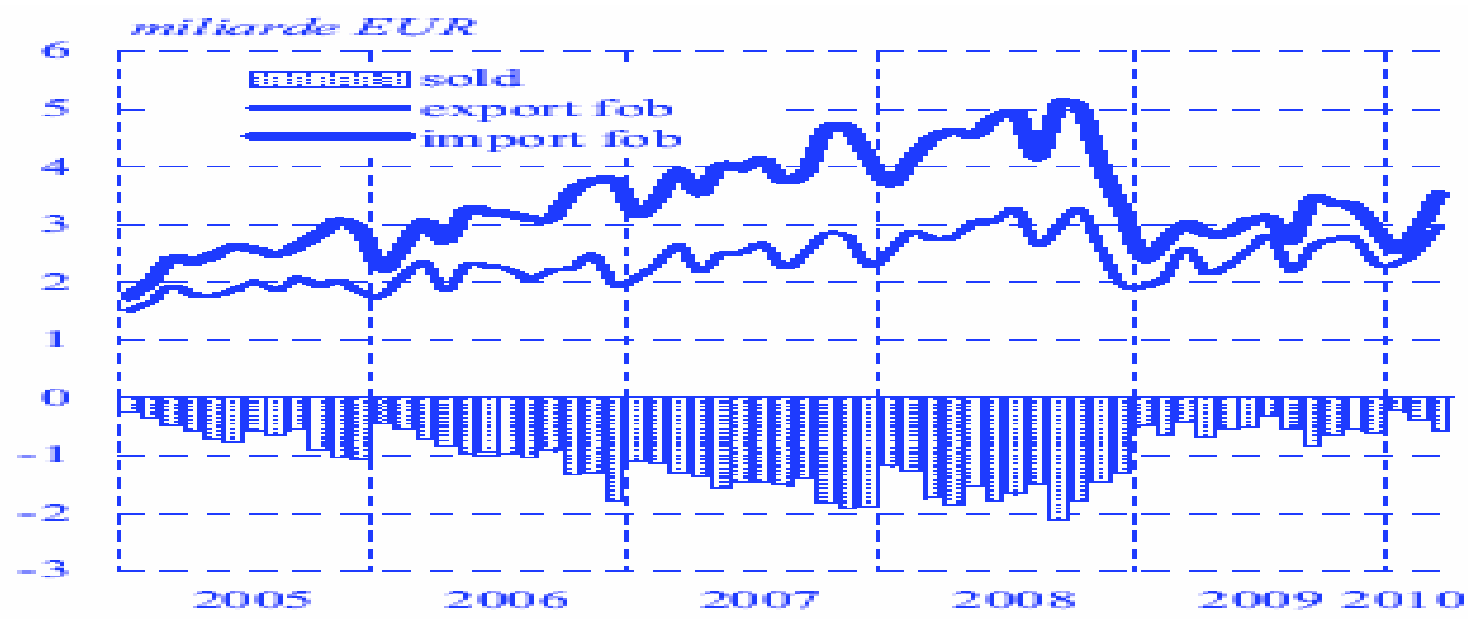

Fig.no. 3.- Trade balance of Romania between 2005-2010 years

The Romania's joining to the European Union involves the single currency adoption ( EURO) ba tur the time horizon depending by the economic integration with the euro area. The euro adoption is a crucial moment for the economy of a Member State, as it implies the transfer of the decision-making power in the monetary field to the European Central Bank. Consequently, the efficiency of the single monetary policy is a conditional upon a high degree of homogeneity among the national economies.

The international financial crisis during 2008-2009 years has led to a slowdown in the exports of the some important sectors of the Romanian economy. Near to the commercial component, the FDI strongly influenced the payments balance of Romania during these economic recession years (M Isărescu, 2009) 


\section{The Attractiveness of the Romanian SME sector between 2008-2010}

Regarding this period, the SME sector has remained really the only sector within a higher contribution to sustainable development of the Romanian economy as it's showning the evolution Business Index evolution calculated by the National Council of SME of Romania by each year.

Business Index - is an indicator based on a set of 13 statistical indicators and it's calculated by adding the score for each indicator, including the maximum value of the Business Index is 100 points ( see table 2)

Table no.2.

The SME contribution quoting by Business Index value

\begin{tabular}{|c|c|}
\hline Business Index value & SME contribution quoting \\
\hline$(-70)-0$ points & Very unsatisfactory \\
\hline $0-25$ points & unsatisfactory \\
\hline $25-50$ points & Satisfactory \\
\hline $50-75$ points & good \\
\hline$>70$ points & Very good \\
\hline
\end{tabular}

According to White Carta of SME sector of Romania the Business Index attractiveness of this sector was enhancement from the 46 points (2009) to 59.13 points in 2010 (see graph. 4 \&5)..

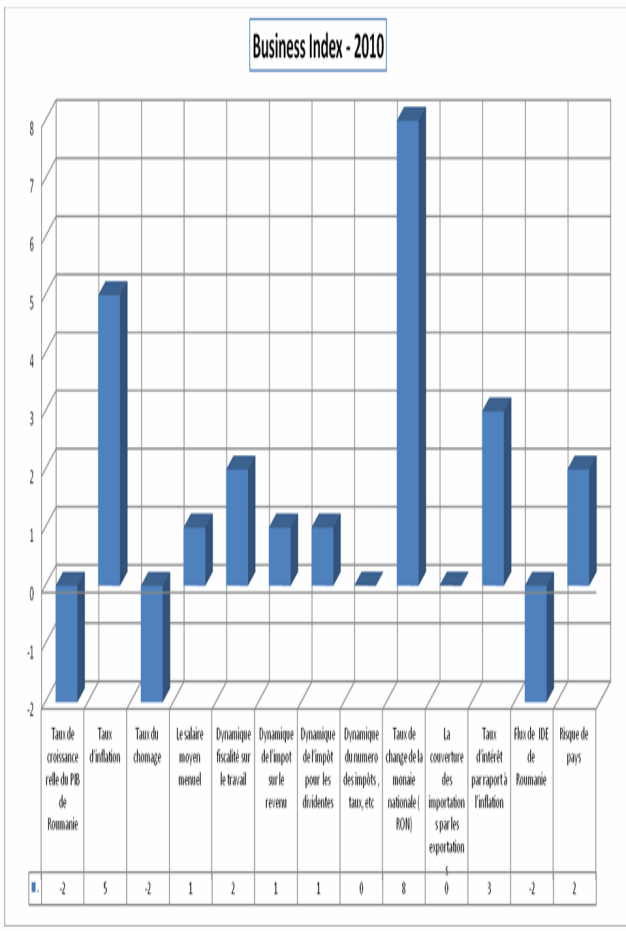

Fig.no 4.- Business Index in 2010*

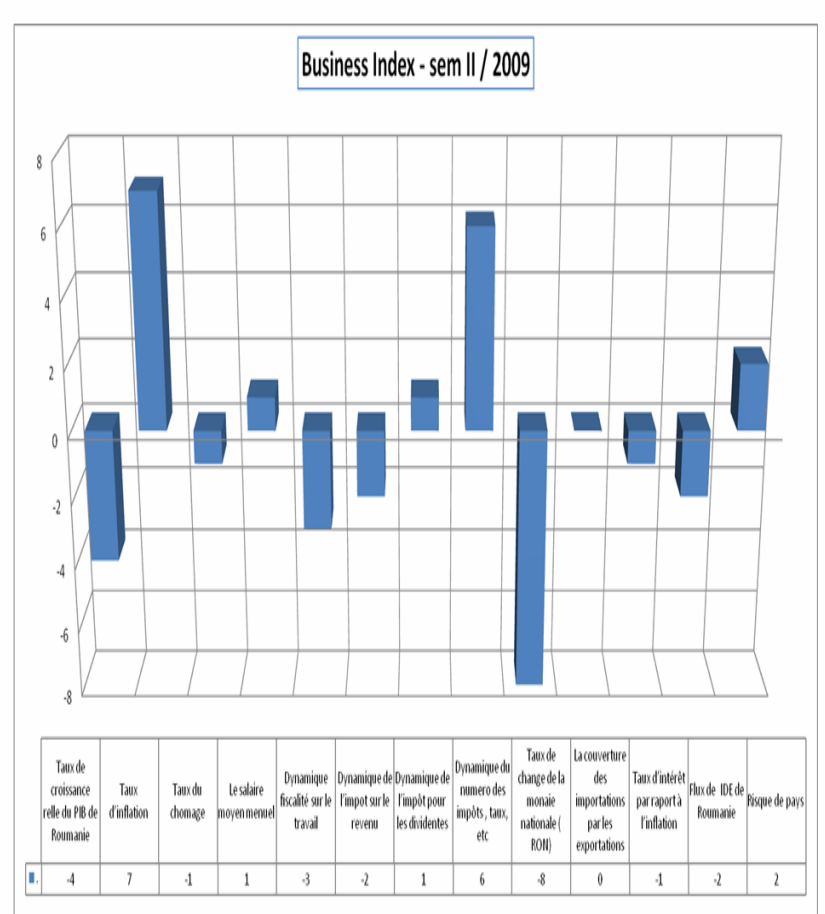

Fig.no. 5. - Business Index in 2009*

\section{Conclusions}

During 2011, the five largest FDI projects provided to 232 million Euro investment value and it will create 1260 jobs as following ${ }^{8}$ :

- 120million Euro investment of Prio company of the Portuguese Martifer Group, into the biodeisel producton is the largest project initiated in 2011 which it will create 80 jobs at Lehliu Gara of Calarasi county; 
- Rochling German Group shall invest 9 million Euro into the plastic automotive components production of Pitesti city that in the first phase the investment provides to 50-60 employees;

- the Germans of Bosch Group will open two production units in Blaj city, Alba county; the investment will reach about 100 million euro and new production hall will be completed up to 2014;

- Lukoil entered on the electricity supply market of Romania and the company has invested into build a central platform of Petrotel refinery of Ploiesti and Lukoil has a 310 gas stations network;

- the real estate transactions volume has exceeded 240 million euros for the $1^{\text {st }}$ Semester 2011, the largest takeover deal being developer Adama for 42.3 million euros, according to Cushman \& Wakefield Consulting Group.

The best news in the first half of 2011regarding the return of consumption of Romania: between January - March 2011 for the first time of the past two years have seen an increase in sales of electronics, home appliances and IT over the same period of 2010. Roumanians bought durable goods worth 307 million euros (10, 7\% compared with $1^{\text {st }}$ Q/ 2010). E-commerce and tourism\&travel industry will arrive to the end of 2011 at 350 million euro compared to 300 million euros (2010). The stars of the Romanian retail are the new distribution formula categoryneighborhood stores, discount and hypermarkets.

In 2010, labour productivity in the economy further decreased year on year (by 1.2\%), albeit at a far slower pace ( -4.6 percentage points). The economic downturn no longer entailed a reduction in workforce, although this indicator. Romania still registers a clearly unfavourable gap in terms of labour productivity, which accounts for only 46 percent of the EU-wide average. Romania, in 2010, further lagged behind peer countries in terms of openness of the economy. Specifically, the sum of imports and exports of goods and services as a percentage of GDP stood at $77.1 \%$, against a low of $84 \%$ in Poland and a high of $165 \%$ in Hungary. However, it should not be overlooked that the indicator improved by a hefty 9.5 percentage points from 2009 thanks to fast-rising exports, which drove imports higher as well ${ }^{7}$.

SME evaluate the government policies and behavior of governments in terms of investment climate in their industries in the light of four interrelated problems: stability and security, regulation and taxation, financing and infrastructure and finally the hand of the work and labor markets. An assessment based on costs, risks and market barriers provide the competition on the market. The economic downturn is already a reality for Romania, uncertainties regarding financial stability, monetary policy is implemented and the precarious conjontural policy, also lead the state to a direction which isn't given the opportunities to come back fast.

Only a collaboration of all macroeconomic policies will restore the imbalance shown by the actions implemented only in a single direction, actions proved inefficient and can generate unintended negative effects pout all sectors the economy of Romania.

To define the defense of economic growth in the medium and long for Romania is absolutely necessary to designate a "project-resources" that does mean:

- to continue the structural reforms that stimulate the growth of labor productivity and competitiveness of Romanian products on external markets.;

- to implement a fiscal and monetary policy more restrictive than those projected;

- to implement an incomes policy that does not add more pressure on consumer demand.

The defense for a long time of economic growth in Romania requires designing the economic and social development by two categories of measures that can help Romania, in our opinion:

a) structural reforms that are necessary to enhance the effectiveness of governance;

b) the Romanian government must design without delay the new objectives of economic resilience in an attempt to resist and then quickly level the effects of the current financial crisis affecting the economy; 
c) for Romania, EU funds may be a solution very efficient and our country must teach by the Poland experience, which it was the only EU member country that had an economic growth during 2009 with an advanced $1.7 \%$, while all other EU member states were in recession, including Romania, which recorded a contraction of Gross Domestic Product of 7.1\% for 2009.

With a view to ensuring Member States' increased competitiveness over the long term and attaining economic convergence both within the euro area and throughout the EU, the President of the European Council and the President of the European Commission drafted a proposal for a Pact that was endorsed at the Euro zone Summit of 11 March 2011. During the European Council meeting (24-25.03.2011), Romania - along with _ ve other non-euro area Member States (Bulgaria, Denmark, Latvia, Lithuania and Poland) - agreed to join the Euro Plus Pact (hereinafter referred to as "the Pact").

The Pact is aimed at: fostering competitiveness; fostering employment; contributing further to the sustainability of public finances and reinforcing financial stability. In addition, fiscal policy coordination will also be taken into consideration.

The key components of the Pact rest on four guiding rules, namely ${ }^{7}$ :

(i) it will be consistent with the existing economic governance in the EU (i.e. Europe 2020, European Semester, Stability and Growth Pact and the new macroeconomic surveillance framework);

(ii) it will be action-oriented and cover priority policy areas that are essential for fostering competitiveness and convergence;

(iii) each year, concrete national commitments will be undertaken by each Head of State or Government;

(iv) participating Member States are fully committed to the completion oft he Single Market which is key to enhancing competitiveness in the EU and the euro area.

As a lesson from the current crisis, we should consider ways how to strengthen the surveillance of competitiveness within our economies and regions. This should help countries to build stronger buffers in good times, to avoid excessive increases in unit labour costs, and in other words, this would prevent from again extending public and private spending beyond sustainable levels and experiencing difficulties similar to the current ones.

Turning to the current difficulties in the international economy, which are having such a strongly negative impact on all advanced economies, we should retain the fact that for many years, the most developed countries in the world have been a great success story: openness to trade and a high degree of flexibility have allowed these countries to benefit substantially from globalisation during the last decades. Today, these countries have a very high income per capita and its are characterised by a skilled workforce, a flexible labour market, moderate taxation and a businessfriendly regulatory environment.

\section{References}

1. Lynch R., 2001. European Marketing, A Guide to the New Opportunities, Kogan Page Ltd Publishing, London, UK

2. Isărescu M., 2009. Finantarea dezechilibrului extern si ajustarea macroeconomica in conditiile crizei financiare. Cazul Romaniei, pp.27-30

3. Trichet J.-C., 2009. The external and internal dimensions of Europe's competitiveness, Institute of International and European Affairs Publishing, Dublin

4. Statiscal Yearbook of Romania, 2005;2006;2007; 2008

5. Annual Report of National Bank of Romania (2010), p.137

6. www.bnr.ro, accesed on 15.09.2010

7. www.businessmagazin.ro, accesed on 01.09.2011

8. www.wall-stree.ro, accesed on 01.08.2010 